\title{
Librarianship from an International Point of View
}

Miss Marinelli is bibliographer, University of Illinois Library.

$\mathrm{T}$ he stature of American librarianship has grown notably during the last decade. It is no longer a profession concerning itself solely with domestic interests, for the demands being made upon it are reaching out into matters of world-wide importance.

American methods are widely admired and imitated. Despite their popularity, it would be well at the outset not to assume that our ways are superior, or that they should be exported in patterns of complete reproduction. Neither should we project ourselves in wholesale fashion without reservation upon other cultures and civilizations, most of which are older than ours, and are for the greater part serving their peoples well. Instead our contribution should be one of guidance and helpful leadership. The subsequent results will necessarily vary, and those combinations which will serve the local pattern, and eventually fit best into the international situation, should be advanced without hesitancy. At the same time our own participation should not be a one-way affair, for there is considerable to be gained from other cultures. It becomes at once both an individual and collective responsibility, to bring back those desirable traits which will enhance our own civilization. Simultaneously there should

1 Presented before the third general session of the annual conference of the Tllinois Library Association. Illinois Association of School Librarians. Medical and Institutional Librarians, the Illinois Chapter of the Special Library Association, Chicago Library Club, at Springfield, III., Nov. 20, 1948. be an awareness of the less desirable phases which in themselves can serve as a caution and a preventative. The process is necessarily a long range one, but one that will eventually make for the widely sought better understanding among nations.

It is within this contemporary picture that the librarian is being called upon to serve. It may be remembered that some 20 years ago the Carnegie Endowment for International Peace made funds available for the rejuvenation of the Vatican $\mathrm{Li}$ brary. It stipulated that by so doing it hoped to promote peace by bringing together the scholars of the world. Librarians from the U.S. and other countries, and faculties from American library schools, cooperated. The idea being promoted today, although on a larger scale, is not new and goes beyond the world of the scholar.

It was with this primary objective in mind that the International Relations Round Table on Library Service Abroad was planned. The conference was conceived and later directed by Mrs. Helen Wessells, as an outgrowth of her experiences as U.S. Information Service librarian and cultural officer in Melbourne, Australia. Following her return in 1947 , and while serving as associate director of the A.L.A. International Relations Office, the plan was fully realized in what is now referred to as the "Williamstown Conference." The meetings were held on the Williams College campus, in Williamstown, Mass., June 2I-28, 1948, with Wyllis E. Wright, librarian, as host. Marie Hurley 
and Marietta Daniels, librarians with foreign experience, served as codirectors. Financial support was provided by a grant received from the Carnegie Corporation of New York. Lodging and food were provided by the nearby Williams Inn, and conditions to approximate those met by a librarian abroad were reproduced wherever possible. Arrangements were so inclusive that not only listed readings but travel schedules, highway routes and wardrobe suggestions were supplied. The inn furnished each delegate with data on every possible recreational facility, and with the surrounding mountains, trails and sports, one's leisure between sessions was well filled. Consequently the hours were not long enough to accomplish all that was planned. The days, however, were satisfying, absorbing and stimulating.

A total of 58 members were in attendance, 30 of whom were resource people, and at times referred to as specialists. The latter came for periods of from two to four days, so that there was a continuous stream of arrivals and departures. The remaining 28 persons were librarians, who upon selection from an A.L.A. roster of some 800 names, automatically became the participants and remained for the entire period. Represented in this group were several library schools, different sections of the country and various types of libraries. A considerable number had spent several years in foreign libraries, some had studied or resided abroad, and others had either traveled extensively or had command of little known languages.

Noteworthy among the latter was Mrs. Patricia Van Delden, chief of Exhibitions and Information Centers in Germany, who was flown to the conference on Army orders. Mrs. Van Delden directs 28 Information Centers in the American occupied zone, as well as a rapidly expanding net- work of reading rooms. Eleanor Townsend, a recent library school graduate, not only served as librarian but on the final day presented her reactions - contrasting, comparing and recommending those phases of the conference that could be incorporated into professional training methods.

Space will not permit a full listing of the resource people, although certain individuals should be mentioned specifically to illustrate the wide variety of backgrounds. Among these were Frederick Cromwell, then director of the A.L.A. International Relations Office; Verner Clapp of the Library of Congress, who had recently returned from a mission to China and Japan; Flora Belle Ludington, then chairman of the A.L.A. International Relations Board, who has since been on a mission to Japan, and had been U.S. Information Service librarian in India; Isabella Jinette, who had just returned from two years of library service for the Tasmanian government and had simultaneously made a Carnegie Corporation of New York survey of library facilities for young people of that country; Lilian Foley, librarian for the Australian government Information Bureau in New York City; Harriet Rourke, then chief of placement for the American Library Association, with responsible library experience abroad during the second world war; Charles Gosnell, New York State Librarian; Carl Milam, director of the United Nations libraries; Eva Antonnen from the Biblioteca Benjamin Franklin of Mexico City; Andy Wilkison, who is now in the Department of State Library at Buenos Aires; Marietta Daniels, of the Pan American Union Library, and Latin American specialist; Mrs. Olga Plunder, then chief of the Army Translation Unit; and Thomas Simpson, reorientation chief of Civil Affairs and Army Education.

The primary objective of the round table 
has already been mentioned. Its aim in furthering and facilitating that purpose was not to train librarians for specific positions abroad, but to set a pattern for future sessions. The plan was to examine objectively the advantages and disadvantages of working abroad, and to suggest methods for the recruiting and training of librarians who, through their personal qualities, professional knowledge and specialized backgrounds, could be recommended to American and foreign governmental agencies, ${ }^{2}$ and to any private groups requesting advisers in the various fields of library service.

The seminar method of approach was used, with both resource people and participants pooling their experiences and subsequently making recommendations. Most of the mornings were devoted to a workshop period, the afternoons and evenings to the interpretation of the U.S., area studies and supplementary information. Free time was usually devoted to policy formulation, committee work and the compilation of recommendations.

The introductory meeting began with a discussion on qualifications sought for the librarian abroad. It was assumed that professional skills are merely one segment of the necessary background. Also desirable are good health and physical endurance, suitable personal traits and adaptability, knowledge and honesty in interpreting one's own country, knowledge of the foreign country concerned and its language, training in psychology and a wide experience in dealing with people.

The professional and personal impacts made upon a foreign community will be affected by the attitude of the local groups,

2U. S. State Department. Division of Libraries and Institutes; UNESCO. Libraries section; Civil Affairs Division, Department of the Army, Reorientation Branch; Special Services Division, Library Branch of the Army, Recreational Services; U. S. Navy Outpost Libraries; Fulbright Act arrangements. whether they are nationals or the more or less permanent American colony. To facilitate an understanding of this situation, some agencies, such as the State Department and Army, use briefing procedures before departure, but private sources of information required consideration. Of utmost importance is the knowledge of political situations, living conditions, cost of living, educational and cultural centers, and many personal matters, such as wardrobe needs which in some cases must be provided for lengthy periods. The problem of establishing oneself simultaneously as an individual and a librarian is not simple, but leadership should be assumed promptly.

The area studies provided an approach to the understanding of foreign people. It has been said that the nations of the world are elementarily informed about civilizations other than their own. In order to avoid distortions, whether inherited or invented, a knowledge of other ways of life becomes fundamental. Using this assumption as the starting point, the series began first with an interpretation of the U.S., the theory being that in order to understand other countries better, a working knowledge and honest interpretation of one's own country becomes basic. Accepting this thesis for his background, Dr. Edward Kennard, cultural anthropologist of the State Department Foreign Service, followed with an excellent lecture on the understanding of foreign peoples. The idea was further developed by Henry Lee Smith, with his presentation of language and culture. $\mathrm{He}$ stressed the importance of linguistic science, for through it is furnished a basis for a more intelligent understanding of peoples. Dr. Smith is the present head of the Foreign Service Language Training Unit of the State Department, and will be remembered for his connection with the development of the Army foreign language training method. 
This cultural and sociological introduction was followed by concentrations on specific areas. John Steeves, chief of the State Department Near East and Africa Area Division, discussed India, a country he has known intimately for 19 years. Emerson Greenaway presented highlights of his 1947 UNESCO European survey, which included information on libraries as well as the countries involved in his study. Colonel Paul West, vice-president of the International Division of McGraw-Hill, a man with a background of many colorful experiences, including paratrooper activities on both sides of the Mediterranean during the recent war, gave his views as publisher to the Latin American and continental trade. In the absence of Carl Sauer, whose plane was grounded by severe rain storms, documentary films prepared for foreign exhibition were shown. Specific mention should be made of the excellent Julien Bryan production filmed for governmental use, which depicts the nostalgic life of a midwestern community, and is entitled Ohio Town.

As the occasion demanded, other impromptu area presentations were made. This was made possible by the heterogeneity of foreign experiences, and the diversity of countries involved. One of the many public contacts of a former librarian in India might be related, for it depicts so well the characteristic pride of regionalism. In her library one morning she was completely surrounded by one of the noteworthy Maharajahs and his colorful retinue. Although outwardly calm, she was quite baffled when the constitution of Vermont was requested. She remembered that the document had been relegated to a rear storage space, with little or no expectancy for use, but it was procurable and presented within due time. The Maharajah reappeared alone on the following day, with the same request. By that time quite consumed with curiosity, the librarian ventured to offer other American constitutions. She was faced with a polite but negative reply, for when on a train journey, the Maharajah had had a GI travel companion who had assured him that that state constitution was by far the best America could offer. Another librarian in speaking of Japan and its literacy, mentioned the following incident in connection with a conversation held with the minister of education. The latter, with the usual diplomatic courtesy, expressed his fervent desire that the U.S. would be a model conqueror, for the Japanese hoped strongly to be a model conquered nation. After all, they were both serving jointly in those capacities for the first time. Other experiences related often illustrated a lack of understanding, not only by civilizations abroad, but by our own as well.

Supplementary sessions included children's and young people's library service, and audio-visual equipment, with recommendations as to selection for use abroad. The entire library plant, with practical problems involved on foreign soil, was given considerable attention. Another session was devoted to library materials necessary for foreign consumption, including books, government documents, periodicals and newspapers.

The personal impact upon a foreign community and the problem of adjustment to life abroad, and protocol, both official and unofficial, were presented by Mr. and Mrs. Frank Boyce. Mr. Boyce has been an official of the State Department Foreign Service until recently, and has served in Latin America, Europe, and Australia. He was in Japan when the last war was declared. Mr. and Mrs. Boyce have now in manuscript form a book on the subject they discussed, ready for publication.

The results of the workshop periods are 
about to be made available in the form of a manual, intended to assist in the orientation of the librarian abroad. The following categories are covered:

I. Qualities necessary for a librarian as an American citizen which will enable him to become a world citizen.

2. Professional knowledge necessary and expected of a library leader.

3. Problems and situations to be encountered both as a citizen and as a librarian.

4. Participation in the free flow of ideas between the U.S. and the rest of the world.

The final day of the round table was perhaps the most important, for in the presence of Assistant Secretary of State George Allen and Mr. Cromwell, with Mrs. Wessells leading the participants, a recapitulation and evaluation of the entire conference were undertaken. The participants unanimously expressed their approval of the objectives outlined. Gratitude was expressed to Mrs. Wessells and to all agencies concerned for the marked success of the initial performance. The general evaluation of the conference was followed by specific recommendations. Organization of institutes, recruiting, and special suggestions to library schools were proposed. A strong issue was made, doubtless based to a great extent by the week-long experience, that librarians open their sanctums more freely and cooperate with subject specialists.

Mr. Allen, who had spoken previously on his own diplomatic experiences and the State Department library service program, presented his evaluation of the round table. His recommendation to those planning to go into the foreign service is as follows: ". . . be a good solid American representative.... The safest route is in the adoption of a good middle ground in 'give' and 'take,' and in matters of controversial nature as well." To serve worthily an American must not lose his identity as an American, for then his usefulness ends.
What developments have occurred since the Williamstown meeting? The machinery has begun toward the fulfilment of the objectives outlined earlier. A resolution has been sent to the Joint Committee on Library Work as a Career, asking that it give adequate attention to foreign library service. Listed suggestions have been compiled for the use of library schools, giving specific recommendations as to how their curricula may provide concrete contributions to foreign library service training.

The need for some form of permanent documentation of the conference proceedings was felt. Mr. Allen expressed interest in having them recorded in a State Department publication. A series of articles on the efforts of the round table, opportunities of library service abroad, and of the importance of librarianship in the development of world cooperation are to be published. These will appear in some of the popular nonlibrary publications as well as in the professional journals. Attempts will also be made to publicize the activity among other agencies that are concerned with the promotion of world understanding and the improvement of international relations.

A petition for American Library Association status of the round table was presented at the Council meeting on Jan. 23, 1949 by Dr. Luther Evans. It was unanimously carried. Since then the group has been known as the American Library Association Round Table for Library Service Abroad. Its first official meeting was called on April 23 in Washington, D.C. Mrs. Wessells, now acting chief of the Libraries Branch, Department of State, presided as chairman. ${ }^{3}$

The following activities have been

${ }^{3}$ The officers elected are Marietta Daniels, chairman; Marion Milczewski, vice-chairman; Katherine Shorey, secretary-treasurer. Four committees were established, secretary-treasurer. Four committees were established,
with the following chairmen appointed: Anne V. Marinelli, Membership and Recruiting; Marion Vosburgh, Editorial; Verner Clapp, Exchange of Persons and Publications; and Clara Fielder, Publicity. 
planned for the year. The Manual on Library Service Abroad, which has been experimented with in the library circles of our occupied zone of Germany, will be revised and published. Meetings of the round table will be planned and held at the A.L.A. regional and midwinter conferences, as well as at the 1950 national conference. The group will cooperate and assist in every possible way with the meeting of the International Federation of $\mathrm{Li}$ brary Associations, which will also take place in 1950. It will assist with the selection of an approved library school within the U.S., which will specialize in an institute designed to benefit Latin American librarians, and which will give background knowledge as well to American librarians interested in going into Latin American library service. Another interest will be concerned with the possibility of planning a preconference meeting near Washington, D.C. in 1950 for another workshop such as the one held in Williamstown. The Foreign Service Roster will be studied, and recommendations drawn will be followed.

Your reporter believes that the initial enthusiasm, loyal participation, and the strong conviction of internationalism in the librarians, whose indefatigable activities she has shared, will be increasingly influential. They have already proved that any obstacle or hardship which has come their way can be met. Participation in activities beyond the U.S. can illustrate best some specific individual undertakings. Two of the three U.S. librarians of the total 50 selected to attend the UNESCO library session in England last summer are active members. One of these, shortly after her return to the states, left for Panama where she taught library courses. One other is well settled in her position as director of the State Department Information Library in Lisbon, and another has a similar post in Pakistan. One has gone to the Biblioteca Benjamin Franklin in Mexico City. Two were to have served with the six librarians selected for the three library institutes in China. Present conditions there, however, will doubtless prohibit this activity for some time to come.

It is hoped that this summary has portrayed in some way the large responsibilities that lie ahead. It is highly desired that others will join in the work described, for the field has been barely explored. The implications involved are of world-wide importance, and contributions are being sought from well-qualified persons. 